\title{
Analysis of a fragmentary diatom record from Lake Van (Turkey) reveals substantial lake-level variability during previous interglacials MIS7 and MIS5e
}

\author{
Samuel M. North • Mona Stockhecke - Yama Tomonaga • Anson W. Mackay
}

Received: 13 April 2016/Accepted: 23 May 2017

(C) The Author(s) 2017. This article is an open access publication

\begin{abstract}
Ancient lake sediments provide opportunities to reconstruct aquatic ecosystems during previous interglacials. In the summer of 2010, the ICDP project PALEOVAN drilled a complete succession of the lacustrine sedimentary sequence deposited during the last $\sim 600,000$ years in Lake Van, eastern Anatolia (Turkey). Previous palaeolimnological analysis of the Lake Van sediment record has shown diatoms to be absent over most of the sequence apart from a short interval during the Holocene. Here, we demonstrate the preservation of additional fragmentary diatom records during Marine Isotope Stage
\end{abstract}

Electronic supplementary material The online version of this article (doi:10.1007/s10933-017-9973-z) contains supplementary material, which is available to authorized users.

S. M. North $(\bowtie)$

Department of Life Sciences, Imperial College London, Silwood Park Campus, London SL5 7PY, UK

e-mail: samuel.north14@imperial.ac.uk

M. Stockhecke

Geological Institute, Swiss Federal Institute of

Technology (ETH), Zurich, Switzerland

M. Stockhecke

Large Lakes Observatory, University of Minnesota,

Duluth, MN, USA

Y. Tomonaga

Department of Water Resources and Drinking Water,

Eawag, Swiss Federal Institute of Aquatic Science and

Technology, Überlandstrasse 133, 8600 Dübendorf,

Switzerland
(MIS) 7 (243,000-191,000 years ago; Lisiecki and Raymo in Paleoceanography 20:PA1003, 2005; Jouzel et al. in Science 317:793-796, 2007) and MIS5e (130,000-116,000 years ago; Lisiecki and Raymo 2005; Jouzel et al. 2007), each spanning no more than a few thousand years. Although brief, the presence of contrasting diatom assemblages between these two interglacials provide a snapshot of varying water depth and, by inference, climate. Analysis of MIS7e samples suggests that lake water levels were low after a period when the lake was open (i.e., high lake levels with the presence of an outflow present), resulting in higher salinities and possibly less stable bottom waters, which switched between anoxic and oxic states more frequently. By contrast, the diatom assemblages

\footnotetext{
Y. Tomonaga

Institute of Geological Sciences, University of Bern, Baltzerstrasse 1+3, 3012 Bern, Switzerland
}

\author{
A. W. Mackay \\ Environmental Change Research Centre, Department of \\ Geography, UCL, London, UK
}


during MIS5e are characteristic of fresh, relatively nutrient rich waters. This suggests that lake levels were high, that the lake was hydrologically open with an outlet, and that the bottom waters were anoxic for long periods of time. Furthermore, our palaeoconductivity estimates and modelling of the past lake volumes with respect to its salt content support the presence of an outflow.

Keywords Lake Van - ICDP project PALEOVAN . Diatom dissolution · Interglacials · Diatoms ·

Palaeohydrology $\cdot$ Lake levels

\section{Introduction}

Ancient lakes (here defined as lakes that formed before the last Interglacial, more than 130,000 years ago (Mackay et al. 2010), provide unparalleled opportunities to investigate the impact of climate change on aquatic and terrestrial ecosystems over several glacial-interglacial cycles. Until relatively recently, comparatively few long-term Quaternary lacustrine records existed (notable exceptions include lakes Baikal (e.g. Williams et al. 1997), Ioannina (also known as Pamvotis; e.g. Roucoux et al. 2008), and Tenaghi Philippon (e.g. Tzedakis et al. 2006) because retrieval of long sedimentary sequences was logistically complex. In 1996, the International Continental Scientific Drilling Program (ICDP; http://www.icdponline.org/) was founded to address this knowledge gap, furthering our understanding of the long-term evolution of past climate across the world, including Africa (e.g. lakes Malawi, Bosumtwi, Challa), southern and northeastern Siberia (lakes Baikal and El'gygytgyn, respectively), China (Qinghai), South and Central America (e.g. lakes Titicaca and Petén Itzá, respectively), and in recent years Europe (e.g. Lake Ohrid) and the Middle East (Dead Sea). Key to reconstructing ecosystem functioning in lakes is an understanding of how primary producers have changed in the past, especially with respect to biodiversity and productivity. Diatoms (Bacillariophyceae) represent an important group of primary producers in many lake ecosystems (Smol and Stoermer 2010), that preserve well in sedimentary environments due to their siliceous cell walls. Diatom studies spanning several interglacial-glacial cycles have been published from several ICDP sites including Lake Baikal (Khursevich et al. 2000), Lake Malawi (Stone et al. 2011) and Lake Titicaca (Fritz et al. 2012). Diatom records from Lake Baikal reveal that orbital forcing is a major driver of Quaternary diatom diversity and productivity, while fossil diatoms from Lake Malawi show distinct lowwater and high-water phases, again linked to orbitalscale variability over the past 144,000 years. Long diatom records from Lake Titicaca on the other hand, reveal complex responses to climatic and non-climatic drivers over the 370,000 years, including tectonic activity and geomorphic processes (Fritz et al. 2012).

Terminal lakes are especially sensitive to climatic change because they are hydrologically dependent on precipitation/evaporation processes (Schindler 2009), which in turn affect the aquatic biota. One of the most recent ICDP sites to be drilled was Lake Van (Turkey; PALEOVAN project; Fig. 1), an ancient, terminal lake located in the climatically sensitive region of eastern Anatolia, between the Mediterranean, Black, and Caspian Seas. The completeness of the $220 \mathrm{~m}-$ long drill core from the Ahlat Ridge (Stockhecke et al. 2014a) indicates that Lake Van never dried out, and contains an archive of past climate and environmental change spanning the past 600,000 years. Seismic profiles reveal that for much of the lake's history, mass-transport deposits dominated the sedimentary record, although elevated regions such as the Ahlat Ridge were unaffected, allowing undisturbed lacustrine sediments to accumulate (Cukur et al. 2014a). Distinct sections (warm/wet periods) of the record are annually laminated (Stockhecke et al. 2014a). Detailed multiproxy analyses of sediment cores extracted in 2010 reveal catchment and within-lake sensitivity to glacial-interglacial cycles. For example, palaeomagnetic values over the past 350,000 years vary with ice core dust fluxes in Antarctica (EPICA; Vigliotti et al. 2014), while pollen analysis reveals high-amplitude climate-driven variability in regional vegetation (Litt et al. 2014). In a detailed lithostratigraphical study, Stockhecke et al. (2014b) were able to separate local factors such as volcanic eruptions and tectonic activity from global climate signals throughout the 600,000-year record, as well as how glacialinterglacial lake-level variations are recorded by the sedimentary processes. Stockhecke et al. (2014b) revealed that diatoms are present in only very restricted sections of the core material, sometimes as thin as $1 \mathrm{~cm}$-thick ('sapropel-like' layers). The 


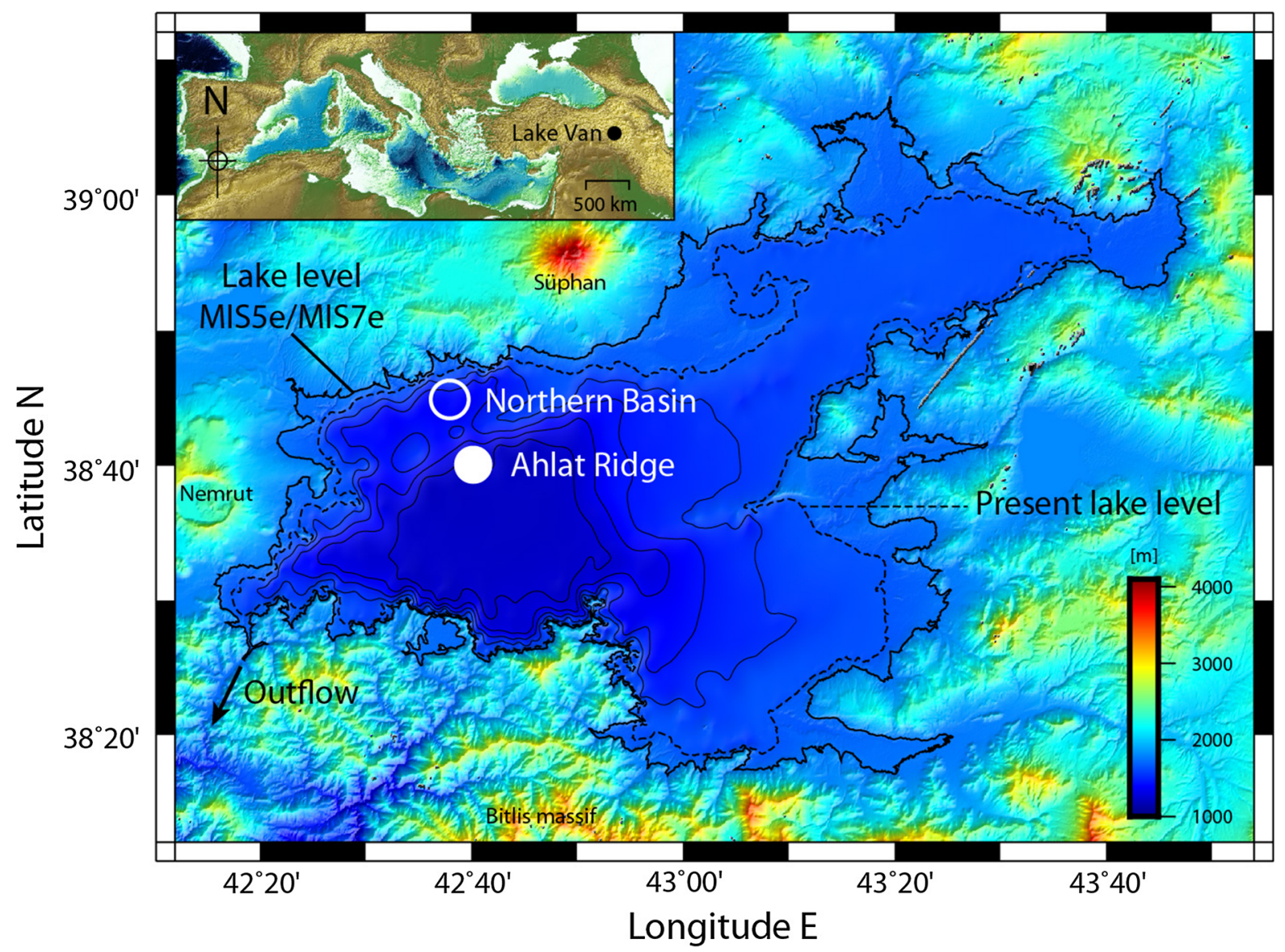

Fig. 1 Map of Lake Van (1648 m a.s.1.), depicting Lake level during MIS7e and MIS5e (black thick line), compared with present day (black dashed line). The position of Lake Van in the context of the Mediterranean area is given in the inset map. Two volcanoes, Nemrut and Süphan, are adjacent to the Lake. The

primary reason is that diatom dissolution is very intense due to the high alkalinity at the sedimentwater interface and in the sediment pore waters (Reimer et al. 2009).

Diatom assemblages can provide important information on past lake hydrology and salinity (e.g. Fritz et al. 2010) because their remains can be identified to the species level and different species prefer specific environmental conditions. Diatoms can also be used to provide quantitative palaeoclimate reconstructions through the application of transfer functions based on robust relationships between species and their environment (Birks et al. 2010; Juggins 2013). In Lake Van, preserved diatom assemblages are associated with fresh, high lake-level phase, perhaps even an open system (Stockhecke et al. 2014b). A recent lake-level
ICDP PALEOVAN drill sites Ahlat Ridge (AR, white dot) and Northern Basin (NB, open circle), and the location of the past outflow are also shown. Bathymetry contours (black thin lines) are drawn at intervals of $100 \mathrm{~m}$

reconstruction based on the modelling of pore water salinity reveals that at the onset of two previous interglacials (MIS7 and MIS5) the presence of an outflow fostered freshwater conditions in Lake Van (Tomonaga et al. 2017). The primary aim of this study is to provide new insight into Lake Van lake-levels during previous interglacials through the application of diatom analysis. We focus our efforts on the previous two interglacials (MIS7e and MIS5e), although several samples from older interglacials (MIS11 and MIS9) were also investigated for comparison.

\section{Lake Van}

Lake Van is the fourth-largest endorheic lake by volume $\left(607 \mathrm{~km}^{3}\right)$, and the largest soda lake in the 
world with an area of $3574 \mathrm{~km}^{2}$ and a maximum depth of $450 \mathrm{~m}$ (Degens and Kurtmann 1978; Cukur et al. 2015). The lake is located on a high plateau in eastern Anatolia (Turkey), at an altitude of $1648 \mathrm{~m}$ above sea level (a.s.l.; Degens and Kurtmann 1978). Lake Van is a tectonic lake, filling the eastern part of a depression that was closed during the late Pliocene (Stockhecke et al. 2012), likely as a result of volcanic activity from the two nearby volcanos: Nemrut (3050 m a.s.1.), to the west, and Süphan (4058 $\mathrm{m}$ a.s.l.) to the north (Stockhecke et al. 2014a; Sengoer et al. 1986; Litt et al. 2012; see Stockhecke et al. (2012) for a more detailed site description). As a result of Lake Van's endorheic nature, its hydrochemical regime is sensitive to any changes or fluctuations in the precipitation/ evaporation ratio (e.g. climate; Lemcke and Sturm 1997; Litt et al. 2012). Water is only lost through evaporation, which, along with hydrothermal activity, chemical weathering of volcanic rocks, and inputs of felsic tephra, have led to the extreme $\mathrm{pH}$ of the lake water ( $\mathrm{pH} \sim 9.6-9.9$, salinity $23 \mathrm{~g} / \mathrm{kg}$; Degens et al. 1984; Kaden et al. 2010; Reimer et al. 2009; Tomonaga et al. 2012). Although diatoms (and chrysophytes) have been found in Lake Van sediment traps, they form only a minor component (c. 6\%; Stockhecke et al. 2012), and are rarely found in bottom sediments (e.g. Stockhecke et al. 2014b).

\section{Materials and methods}

Lithostratigraphy and chronology of the PALEOVAN drill cores

In the summer of 2010, the ICDP PALEOVAN project drilled a complete succession of the lacustrine sediment sequence deposited during the last $\sim 600,000$ years in Lake Van (Litt et al. 2012). Sediment cores were retrieved from the Ahlat Ridge (AR, ICDP Site 5034-2) at a sediment depth of $220 \mathrm{~m}$, and in the Northern Basin (NB, ICDP Site 5034-1) at a sediment depth of $140 \mathrm{~m}$ (Litt et al. 2012). To ensure a complete sedimentary section was obtained, multiple cores were collected at each site and a composite record for the lake was constructed with 231 sections for AR, and 142 sections for NB (Stockhecke et al. 2014a). Although no diatoms were found in glacial sediments, light microscopic analysis of smear slides (Stockhecke et al. 2014a) and biogenic silica contents
(Stockhecke, unpublished), clearly identified intervals to potentially establish a diatom fossil record during the interglacials. The lithostratigraphy confirmed the unique value of the use of Lake Van sediments as natural climate archive covering at least six glacial/ interglacial cycles (Stockhecke et al. 2014a).

The age model of the complete sedimentary sequence recovered from Lake Van is detailed in Stockhecke et al. (2014b, 2016). The chronology was determined from a variety of dating techniques, including absolute and radiometric dating (varve chronology, radiocarbon dating, and ${ }^{40} \mathrm{Ar} /{ }^{39} \mathrm{Ar}$ single-crystal dating), and relative dating (tephrostratigraphy, magnetostratigraphy, ${ }^{10} \mathrm{Be}$ measurements and climatostratigraphic alignment) techniques. The $\delta^{18} \mathrm{O}$ NGRIP and synthetic Greenland record were used as reference records (Barker et al. 2011; Cheng et al. 2009; Andersen et al. 2004; Rasmussen et al. 2006; Svensson et al. 2008). All data presented use the refined chronology by Stockhecke et al. (2016). Marine Isotope Stage boundaries follow Lisiecki and Raymo (2005) and the nomenclature of the substages follow Jouzel et al. (2007).

\section{Diatom analyses}

Fifty-seven sediment samples were initially selected for diatom analysis from interglacial regions with high biogenic silica, which we assumed would contain well preserved diatoms. We focussed mainly on MIS7 ( $\mathrm{n}=29$ ) and MIS5e $(\mathrm{n}=23)$, although a few samples from MIS11 and MIS9 were also investigated $(n=5)$. Sediment samples were prepared for diatom counting using standard procedures, including oxidation of organic material using $30 \% \mathrm{H}_{2} \mathrm{O}_{2}$, and removal of carbonates using a few drops of $10 \% \mathrm{HCl}$ (Battarbee et al. 2001), before being mounted on slides with Naphrax which has a refractive index of 1.73). However, even though sediments with high biogenic silica and organic carbon content were targeted for diatom analysis, the majority of prepared samples either contained too few diatoms to be representative of a palaeo-assemblage, or did not contain diatoms at all. These are listed in Supplementary Information, Table S1. When diatoms were present, at least 300 valves were counted using oil immersion phasecontrast on a Zeiss Axiostar Plus light microscope at $1000 \times$ magnification. Several samples contained only low concentrations of diatoms (Table S1) and in these 
cases, six complete transects were counted instead to ensure even coverage of the slides being examined. Taxonomic identifications were undertaken using a range of flora (including Gasse 1986; Krammer and Lange-Bertalot 1986, 1988, 1991a, b; Sundbäck 1987; Sayer 1997; Kelly et al. 2005; Guiry and Guiry 2014). Diatom concentrations (valves per gram of dry sediment) were estimated by the addition of divinylbenzene microspheres (Battarbee and Kneen 1982). The extent of dissolution was routinely assessed in MIS7 and MIS5e samples using a diatom dissolution index (DDI; Eq. 1) constructed specifically to capture potential palaeoenvironmental information from sediments where diatom preservation can be poor (Ryves et al. 2006):

$D D I=\frac{\sum_{s=1}^{s=4} n_{s} \cdot(S-1)}{N \cdot\left(S_{\max }-1\right)}$

where $\mathrm{n}=$ number of valves in stage $\mathrm{S}, \mathrm{N}=$ total number of classified valves; $S_{\max }=$ highest stage possible if dissolution of valves reached their end point, where $S_{\max }$ is between 2 and 4 .

Diatom diversity and palaeoproductivity

Hill's N2 diversity was estimated because it is a measure of the importance of very abundant species (Birks et al. 2016), which in Lake Van consisted mainly of planktonic species. As an approximate measure of diatom productivity, mean sample biovolumes (valves $\mu \mathrm{m}^{3} / \mathrm{g}$ ) were calculated based on diatoms conforming to a series of geometric shapes (Hillebrand et al. 1999), as diatom concentration could not be taken as a measure of productivity due to the effects of dissolution. For a sufficient representation of the average biovolume of a particular taxon, 15 cells from each taxon with $>5 \%$ in any one sample were measured. The valve depth of centric genera such as Cyclotella and Stephanodiscus was determined as half of the diameter, following Anderson (1994).

\section{Diatom-inferred palaeoconductivity}

Palaeoconductivity estimates were undertaken using locally-weighted weighted averaging (LWWA) regression based on the combined salinity training sets (including sites from East and North Africa, the Caspian lowlands, and Spain) available from the European Diatom Database (EDDI; Juggins 2001).
Reconstructed conductivity values were generated using ERNIE (v.1.2), a software package within EDDI (Juggins 2001). LWWA reconstructions were undertaken with inverse deshrinking, based on the 50 closest analogs in the combined salinity training set for each fossil sample. Closest analogues were determined by minimum squared Chi squared distance. Jack-knifed prediction error of the model (root mean square error of prediction; RMSEP jack) was $0.47 \log _{10} \mu \mathrm{S} / \mathrm{cm}$, with an $r^{2}=0.77$.

Multivariate data analyses

Detrended correspondence analyses (DCA) were initially undertaken on relative abundances of each of MIS7 and MIS5e diatom datasets to establish the magnitude of beta diversity. Relative abundance data were square root transformed in order to stabilize species variance, and rare species were downweighted. In each case, the axis 1 gradient length (measured in standard deviation units) was under three (Table 1), indicating that linear ordination techniques were appropriate for analyses (Lepš and Šmilauer 2003). Principal component analysis (PCA), with square root transformation of the species data were undertaken on MIS7 and MIS5e datasets. A final DCA was run on a combined dataset of MIS7 and MIS5e samples, but also including samples from MIS11 and MIS9. Ordinations were carried out using CANOCO 4.5 (Lepš and Šmilauer 2003). Importance of the DCA and PCA first ordination axes were tested with a broken stick model (Jollifer 1986) using BSTICK v1.0 (Line and Birks 1996), and each was found to be significant.

Palaeosalinity and past lake level estimations

In terminal lakes such as Lake Van, salinity can be inversely proportional to the volume of the water body (Tomonaga et al. 2014, 2017). To estimate past lake volumes (and the respective levels) from the palaeoconductivities (PC) presented in this work we assumed a linear relation between average conductivity $(\mathrm{C}=20.2 \pm 4.6 \mathrm{mS} / \mathrm{cm})$ and total dissolved solids (TDS $=22.8 \pm 0.6 \mathrm{~g} / \mathrm{kg}$ ) determined in water samples collected from Lake Van in 2006. We used an empirical factor $(\mathrm{F}=\mathrm{TDS} / \mathrm{C}=1.1 \pm 0.3 \mathrm{~g} \mathrm{~cm} / \mathrm{kg}$ / $\mathrm{mS}$ ) to convert the PCs into palaeosalinities (PS with $\mathrm{PS}=\mathrm{PC} \cdot \mathrm{F})$. It should be noted that our first-order estimation of the PSs considers a $\mathrm{C}$ value that has been 
Table 1 Summary information from indirect ordination analyses on diatom data counted during the period of MIS7e, MIS5e, and all interglacial samples. DCA was initially undertaken on each dataset, and because axes one gradients were low for MIS7e and MIS5e, these were subsequently reanalysed using PCA

Axis 1 Axis 2 Axis 3 Axis 4

\begin{tabular}{|c|c|c|c|c|}
\hline \multicolumn{5}{|l|}{ MIS7e } \\
\hline \multicolumn{5}{|c|}{ DCA axis 1 gradient $=2.743$} \\
\hline \multicolumn{5}{|l|}{ PCA } \\
\hline Eigenvalues & 0.554 & 0.225 & 0.107 & 0.041 \\
\hline $\begin{array}{c}\% \text { Variance } \\
\text { explained }\end{array}$ & 55.4 & 22.5 & 10.7 & 4.1 \\
\hline \multicolumn{5}{|l|}{ MIS5e } \\
\hline \multicolumn{5}{|c|}{ DCA axis 1 gradient $=1.766$} \\
\hline \multicolumn{5}{|l|}{ PCA } \\
\hline Eigenvalues & 0.443 & 0.229 & 0.153 & 0.123 \\
\hline $\begin{array}{c}\% \text { Variance } \\
\text { explained }\end{array}$ & 44.3 & 22.9 & 15.3 & 12.3 \\
\hline \multicolumn{5}{|l|}{ All MIS } \\
\hline \multicolumn{5}{|c|}{ DCA axis 1 gradient $=3.507$} \\
\hline \multicolumn{5}{|c|}{ DCA total interia $=2.175$} \\
\hline \multicolumn{5}{|l|}{ DCA } \\
\hline Eigenvalues & 0.742 & 0.198 & 0.056 & 0.042 \\
\hline $\begin{array}{c}\% \text { Variance } \\
\text { explained }\end{array}$ & 34.1 & 9.1 & 2.6 & 1.9 \\
\hline
\end{tabular}

determined using conductivities measured both in the epilimnion and in the hypolimnion, while the rather large uncertainty of $\mathrm{C}$ reflects the temperature effect on conductivity. As in Tomonaga et al. (2017), we merged a high-resolution digital elevation model (Farr et al. 2007) and the bathymetry data for the lake (Turkish Office of Navigation, Hydrography and Oceanography 1990) to obtain a complete three-dimensional representation of the lake basin, which we then used to infer the volume of water necessary to produce the variation in dissolved salt concentration (with respect to the present salinity and volume of Lake Van) that would be necessary to yield the estimated PSs.

\section{Results and discussion}

Despite diatoms living in modern Lake Van and their remains being recorded in sediment traps (Stockhecke et al. 2014a), their frustules are almost entirely absent from most of the sedimentary record investigated. Previous studies have also recorded very poor preservation of diatoms in Lake Van sediments. For example, Golubic and Buch (1978) investigated seven cores but only found preserved diatoms in three of these, in sections that they associated with turbidity currents and sediment slumping (i.e. periods of rapid sediment accumulation). Reimer et al. (2009) suggested a narrow period of good diatom preservation between 6.2 and $3.7 \mathrm{ka} \mathrm{BP}$ (out of a $15 \mathrm{ka}$ record), was the result of an anoxic, deep-basin brine, concurrent with high lake levels (Wick et al. 2003). We also record short periods of time during previous interglacials (Figs. 2, 3), when diatom concentrations are high enough to obtain quantitative assemblages. A key question therefore relates to the conditions under which diatoms disappear from the sedimentary record. Either they are not growing at all, which seems highly unlikely, or that their frustules are undergoing dissolution, for example in the water column, at the sediment-water interface, or in the pore waters of the sediments themselves. A comparison of the times of occurrence of the peaks in total mass flux in Lake Van at shallow and deep traps (Stockhecke et al. 2012), revealed that the maximum time taken for particles to settle between the two traps $(405 \mathrm{~m})$ was $\sim 70$ days in 2007 and $\sim 30$ days in 2008. This suggests that there could be time for frustules to dissolve in the water column prior to settling, as also indicated by the high Si concentration (Reimer et al. 2009) in the bottom water of the lake. The dissolution of diatoms in sedimentary records is obviously problematic from a palaeoecological perspectivetaxonomic identifications become more difficult, poorly silicified taxa may be preferentially dissolved leading to biased records, and if dissolution is especially severe, as in Lake Van, no valves may be preserved at all, limiting palaeoenvironmental reconstructions (Ryves et al. 2008). We acknowledge that dissolution is likely to have had an impact on the quality of finding closest analogues between Lake Van sediment samples and the combined salinity training set (Juggins 2001), and on reconstructed palaeosalinity values themselves (e.g. see Ryves et al. 2006). However, the reconstructions offer a potential snapshot of previous water levels in the lake, even if only for a relatively short period of time. And although absolute values may be uncertain, relative comparison of values between the different marine isotope stages, we believe such analyses interesting and warranted, as long as caveats described are considered. 


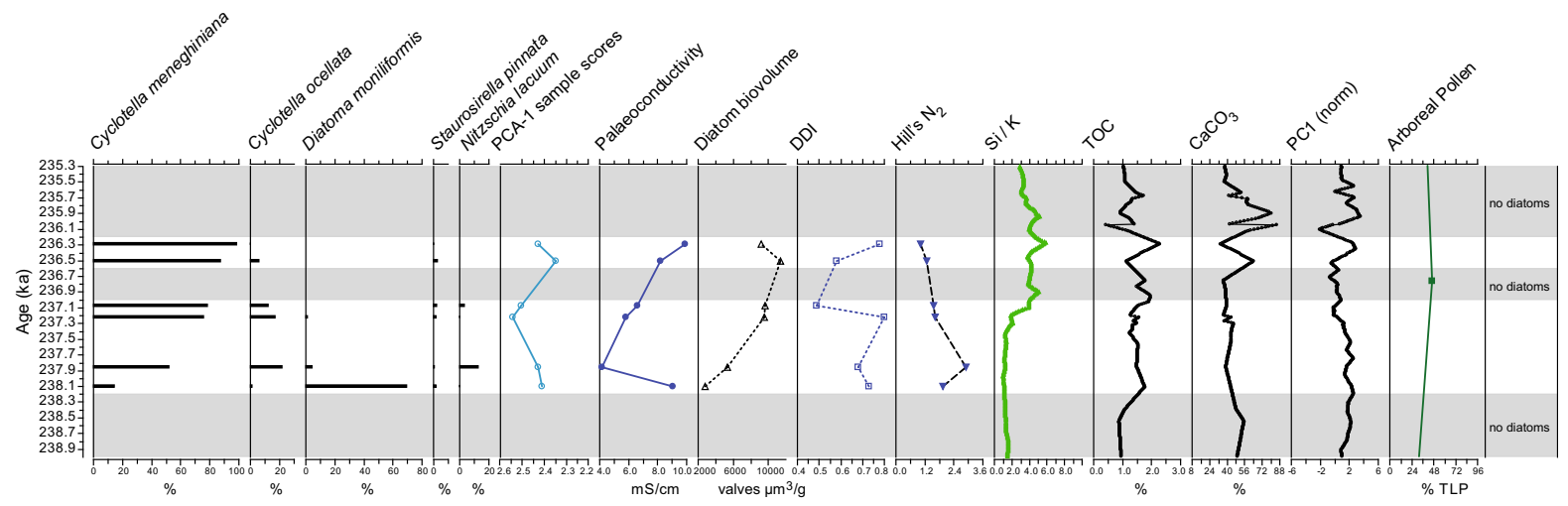

Fig. 2 Mutliproxy stratigraphic analyses for MIS7e. Analyses shown are for periods where diatom concentrations were high enough for to obtain quantitative assemblages. Grey shaded areas are those regions of the core where no diatoms were preserved. TOC $(\%)$ and $\mathrm{CaCO} 3(\%)$ from Stockhecke et al. (2014a), PC1 from Stockhecke et al. (2016), Arboreal Pollen from Litt et al. (2014)

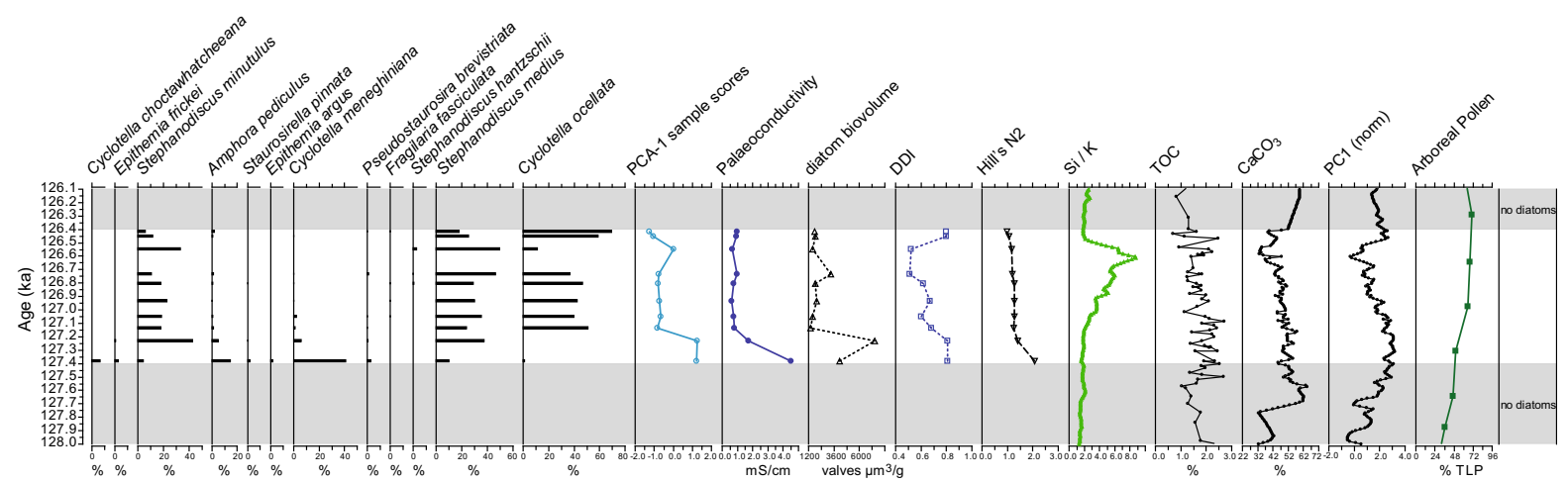

Fig. 3 Mutliproxy stratigraphic analyses for MIS5e. Analyses shown are for periods where diatom concentrations were high enough for to obtain quantitative assemblages. Grey shaded areas are those regions of the core where no diatoms were

Diatom dissolution has been described in many saline lakes around the world, including the northern Great Plains of North America (Ryves et al. 2006), sub-Saharan Africa (Gasse et al. 2002), and the Bolivan Altiplano (Badaut and Risacher 1983; Fritz et al. 2010). The extent of dissolution depends mainly on the chemical composition of the lake water, i.e. brine type, although high $\mathrm{pH}$ can also be important (Fritz et al. 2010). Early experimental work by Barker (1990) showed that maximal dissolution rates and saturation levels occurred in $\mathrm{Na}_{2} \mathrm{CO}_{3}$ brines. Dissociation of silicic acid was further enhanced at $\mathrm{pH}$ values $>9$. It is highly likely therefore that diatoms are generally poorly preserved in Lake Van because of the composition of the lake water: it is a soda lake whose chemistry is dominated by $\mathrm{Na}_{2} \mathrm{CO}_{3}$, (Degens et al. preserved. Si/K ratio from Kwiecien et al. (2014), TOC (\%) and $\mathrm{CaCO}_{3}(\%)$ from Stockhecke et al. (2014a), PC1 from Stockhecke et al. (2016), arboreal Pollen from Litt et al. (2014)

1984), its salinity is high (approximately $23 \mathrm{~g} / \mathrm{kg}$; Degens et al. 1984; Tomonaga et al. 2012) and the $\mathrm{pH}$ of its bottom waters is approx. 9.9 (Reimer et al. 2009). Diatoms in freshwater lakes may also be subject to dissolution, especially where there is intense recycling of organic matter at the sediment surface-water interface, such as Lake Baikal (Ryves et al. 2003). In Baikal, diatoms preserved in lake sediments exhibit bias towards more robust taxa during interglacials (Battarbee et al. 2005), and are very infrequent during glacial periods, possibly because of persistent biological activity at the surface sediment-water interface, when primary production is already low (Mackay 2007).

So, the interesting question is why periods in the Lake Van sediment record are occasionally found 
where diatom preservation is very good. Reductions in diatom dissolution have been observed in meromictic lakes (e.g. Hecky and Kilham 1973; Ryves et al. 2006), especially those that are very saline and have anoxic bottom waters, resulting in a reduction in $\mathrm{Si}$ saturation concentrations (Ryves et al. 2006). However, other factors may also help promote diatom preservation in anoxic bottom waters, including reductions in bioturbation and changes in organic matter content. The pore space of Lake Van is known to strongly suppress diffusive transport (Tomonaga et al. 2011, 2014), and might be an intrinsic property of the sediment column hampering secondary biogeochemical processes, which then affects the diatom record. It has been shown that anoxia of bottom waters in Lake Van is promoted by reductions in deep-water renewal linked to increasing freshening of surface waters and stronger stratification during periods of lake-level rise (Kaden et al. 2010). Where we have diatom preservation in Lake Van sediments, TOC is also better preserved (e.g. Figs. 2, 3), indicative of a productive, stratified lake with bottom-water anoxia (Stockhecke et al. 2014a).

\section{MIS7e diatom assemblages}

Overall diatom preservation during MIS7 is poor. Our sampling resolution is very low, but levels containing enough diatoms were mainly found during MIS7e [although one sample during MIS7a at 197.6 ka BP also contained diatoms (Table S1)]. Preservation of diatoms is best between 238.1 and $236.3 \mathrm{ka} \mathrm{BP}$, with a short period of no diatoms preserved between 237.0 and $236.6 \mathrm{ka} \mathrm{BP}$ (Fig. 2). The epiphytic diatom Diatoma moniliformis (Kützing) dominates the early record. It is a brackish species that grows well in littoral zones, attached to aquatic macrophytes (e.g. Potapova and Snoeijs 1997). It is likely therefore that Lake Van was relatively shallow at this time. The replacement of this taxon with Cyclotella meneghiniana (Kützing) (a cosmopolitan species commonly found in brackish water; Hecky and Kilham 1973), Cyclotella ocellata Pantocsek, and Nitzschia lacuum Lange-Bertalot, is indicative of alkaline brackish waters (e.g. Kelly et al. 2005), i.e. Lake Van deepened albeit with persistent littoral habitats. As MIS7e progresses, C. meneghiniana gradually increased to almost a monospecific assemblage by $236.5 \mathrm{ka} \mathrm{BP}$, leading to very low Hill's $N 2$ diversity but high diatom biovolume-inferred productivity and high palaeoconductivity. C. meneghiniana competes well in silica-rich, saline environments, with a maximum growth rate at water temperatures between 23 and $26{ }^{\circ} \mathrm{C}$ (Shafik et al. 1997; Kelly et al. 2005; Mitrovic et al. 2010), and is also commonly found in large lakes that fluctuate between brackish and freshwater states (e.g. Hecky and Kilham 1973; Gasse 1986). This suggests that the hydrology of Lake Van may have been quite unstable during MIS7e, leading to the resumption of diatom dissolution when periods of anoxia came to an end (e.g. between 237.0 and 236.6 ka BP; Fig. 2). Declining Hill's N2 diversity suggests that few resources were limiting in Lake Van during periods of increasing palaeoconductivity (Interlandi and Kilham 2001a, b), although it is not clear if dissolution plays a major role in affecting species diversity, even during periods when preservation is apparently good.

\section{MIS5e diatom assemblages}

Diatoms were only preserved in meaningful numbers for a very short period during MIS5e, c. 127.4-126.4 ka BP (Fig. 3). Before and after this time either diatoms were present at only very low numbers (i.e. under 30 valves present after six transects counted) or were absent altogether. Dissolution is extensive, with greatest DDI values at the lower and upper end of the diatom period, suggesting that dissolution is likely why we have no diatoms before 127.4 and after $126.4 \mathrm{ka} \mathrm{BP}$, rather than no diatom growth.

The bottom of the diatom sequence is dominated by C. meneghiniana, indicative again of a hydrologically unstable lake, perhaps alternating between freshwater and brackish conditions (Hecky and Kilham 1973; Houk et al. 2010). Hill's N2 diversity is relatively high at this time, indicative of a high number of limiting resources (Interlandi and Kilham 2001a, b) allowing several periphytic and planktonic taxa to co-exist. Higher abundances of periphytic diatom species in climate-sensitive lakes are frequently used to infer lower lake levels and concomitant increased benthic habitat availability (e.g. Stager et al. 1997; Gasse et al. 2002; Fritz et al. 2010). In Lake Malawi, Stone et al. (2011) take a more nuanced approach, attributing periods of higher periphytic taxa to periods of fluctuating water levels; that is, more habitats become 
available when the lake levels are rising and falling. Our assemblage suggests that Lake Van was a relatively shallow (compared to present lake level), brackish-saline lake with extensive littoral habitats during the early stages of MIS5e.

If we use the Holocene sediments as an analogy of what may have happened during previous interglacials, we can speculate that high lake levels between 127.4 and $126.4 \mathrm{ka}$ BP resulted in conditions where a fresher lake resulted in better diatom preservation due to bottom-water anoxia (Stockhecke et al. 2014a). When diatom preservation was good, assemblages are dominated by planktonic diatoms characteristic of lakes with relatively stable stratification and reduced turnover. Small Stephanodiscus species such as $S$. medius and small Cyclotella species such as $C$. ocellata do not sink very fast out of the photic zone, and have been used as indicators of lakes with reduced windiness and greater stratification (Gasse et al. 2002; Oliva et al. 2008; Winder et al. 2009). Stephanodiscus species generally have low requirement for $\mathrm{Si}$, but high requirements for P (Kilham et al. 1986; Kelly et al. 2005; Cruces et al. 2010). High abundances of Stephanodiscus suggests therefore that during MIS5e, Lake Van was perhaps in a mesotrophic or eutrophic state, linked to a warm, wet climate (e.g. Kukla et al. 2002).

Rapidly declining PCA scores between 127.2 and 127.1 ka BP (Fig. 3) reflect the establishment of $C$. ocellata, a diatom characteristic of mesotrophic waters, which grows well in both planktonic and littoral habitats (Kiss et al. 2012) or when summer stratification is strong (Winder et al. 2009). When it is co-dominant with Stephanodiscus species, conditions were likely favourable for diatom growth with good silica preservation, reflected in increasing $\mathrm{Si} / \mathrm{K}$ ratios (Fig. 3; Kwiecien et al. 2014). So perhaps here the lake is at its freshest, with lowest $\mathrm{pH}$, and was hydrologically open (Stockhecke et al. 2014a; Tomonaga et al. 2017). At the end of this period, between 126.5 and 126.4 ka BP, C. ocellata dominates the assemblage, with concomitant low N2 values (Fig. 3), indicative of few limiting resources; $C$. ocellata is a good competitor under nutrient-poor conditions (Winder et al. 2009).

\section{Interglacial comparisons}

Based on the premise that sediment samples with similar floristic composition plot close to each other in ordination space, DCA of all diatoms analysed (Table 1; Fig. 4) reveals diatom composition of the few samples from MIS11 and MIS9 to be distinct from samples counted for MIS7e and MIS5e. The position of diatom species on this biplot represents their maximum abundance in the dataset analysed, such that the further samples are away from the maximum abundance, the less likely that that species is present in those samples. The few samples analysed for MIS11 and MIS9 stages are characterized by very high abundances of Cyclotella choctawhatcheeana Prasad, a diatom characteristic of saline, alkaline, and often highly stratified waters (e.g. Prasad et al. 1990; Oliva

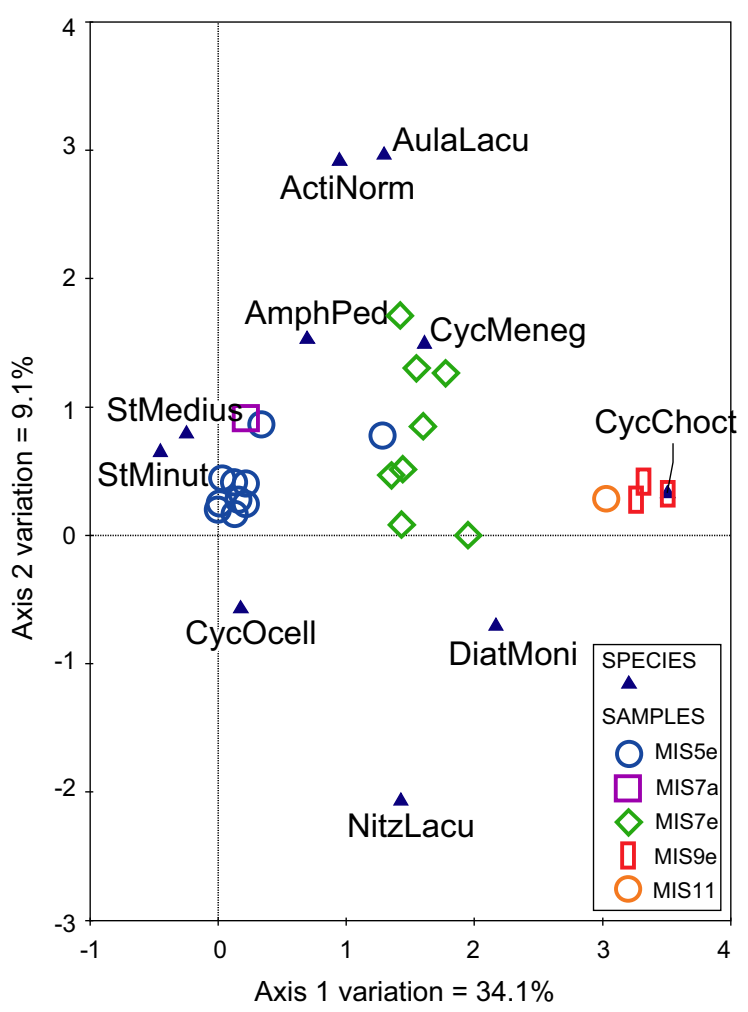

Fig. 4 Detrended correspondence analysis (DCA) of diatom samples analysed in this study. Samples are coded according to which interglacial period they occur. Axis 1 explains the majority of the variation in the dataset $(34.1 \%)$, while axis 2 only explains $9.1 \%$. Therefore the strongest gradient is represented by samples which MIS5e to the left of the biplot to MIS9 and MIS11 to the right of the biplot. Diatom species codes are as follows: ActiNorm Actinocyclus normanii, AmphPed Amphora pediculus, AulaLacu Aulacoseira lacustris, CycChoct Cyclotella choctawhatcheeana, CycMeneg Cyclotella meneghiniana, CycOcell Cyclotella ocellata, DiatMoni Diatoma moniliformis, NitzLacu Nitzschia lacuum, StMedius Stephanodiscus medius, StMinut Stephanodiscus minutulus 


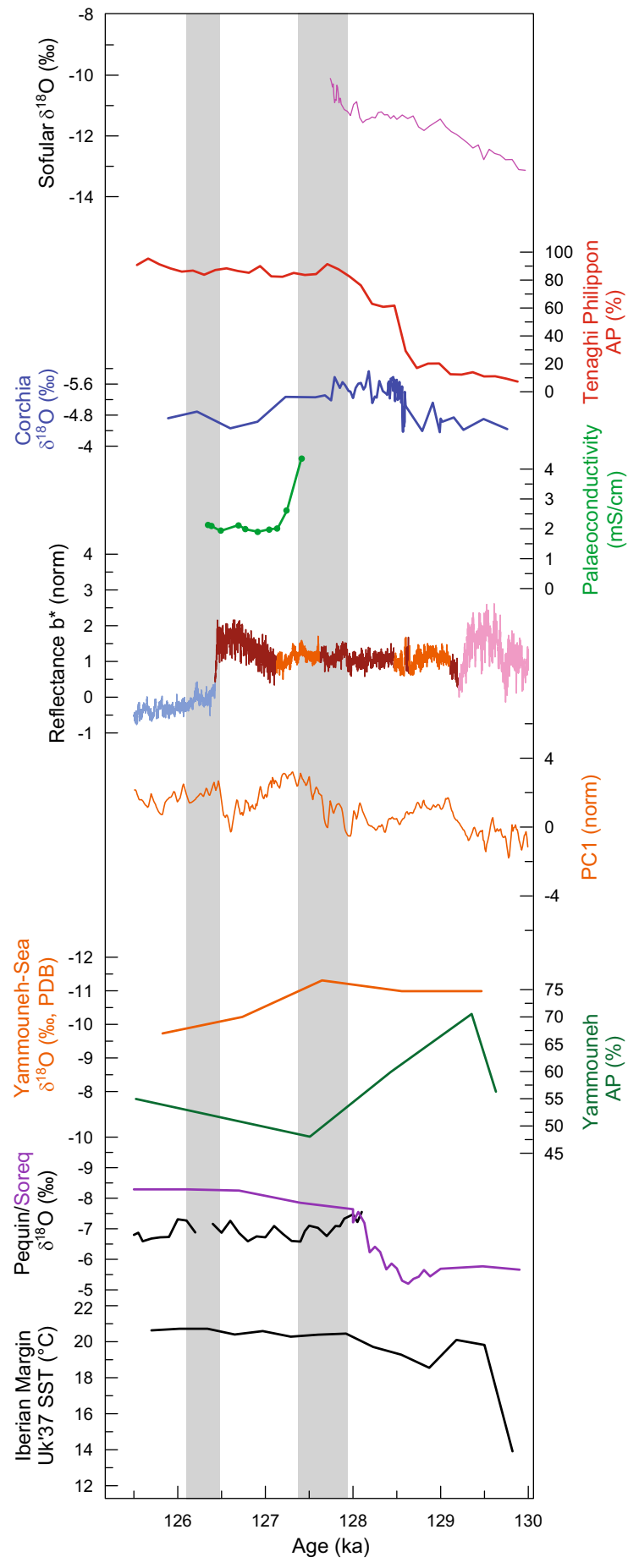

Fig. 5 Lake Van regional archive comparison for MIS5e (left) and MIS7 (right). Arboreal pollen (AP in \%) from Tenaghi Philippon (Milner et al. 2013; Tzedakis et al. 2006), $\delta^{18} \mathrm{O}(\%$ ) from Corchia cave (Drysdale et al. 2005), Lake Van paleoconductivity (mS/cm; this study) as well as Reflectance b* (norm; Stockhecke et al. 2016), PC-1 (Stockhecke et al. 2016), AP and

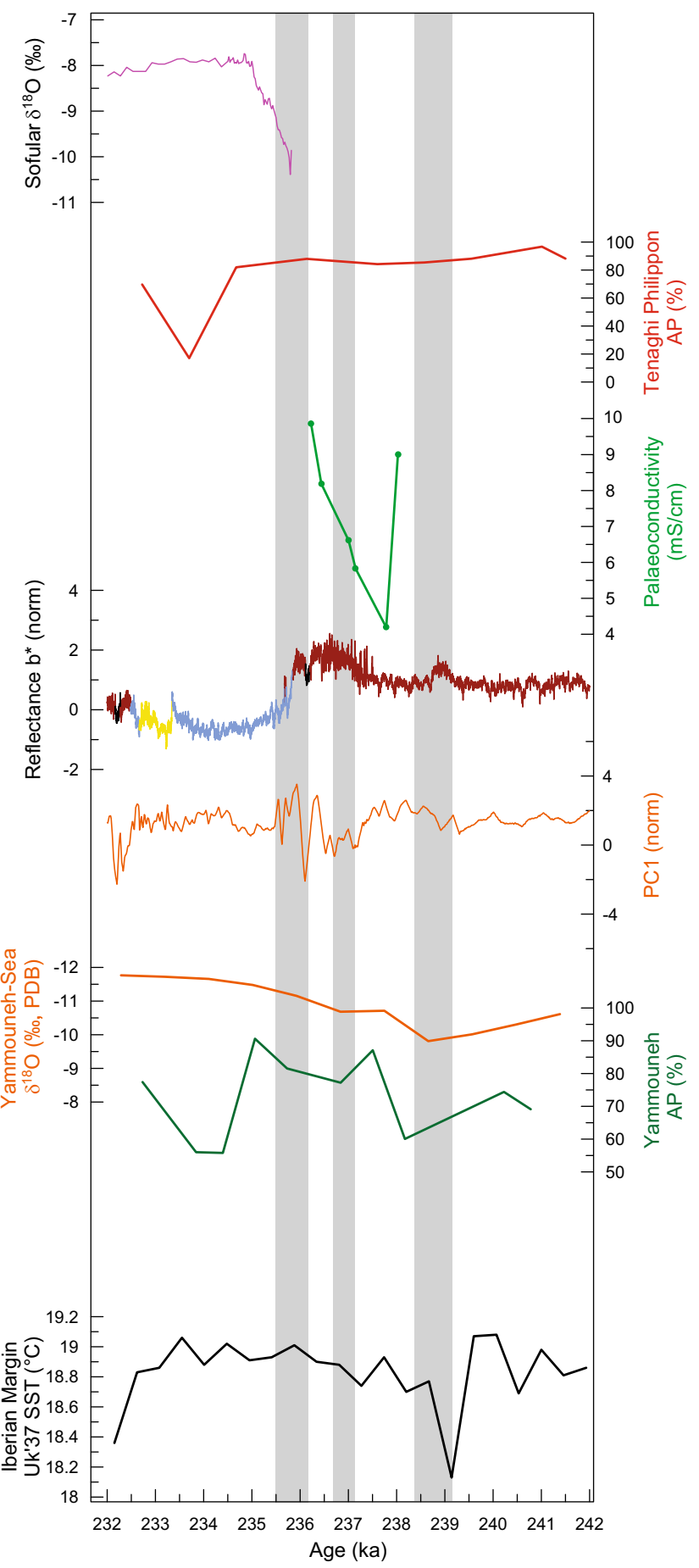

$\delta^{18} \mathrm{O}$ Yammouneh Sea (\% PDB; Gasse et al. 2015), $\delta^{18} \mathrm{O}(\% \mathrm{o})$ from Pequin/Soreq caves (Bar-Matthews et al. 2003), and Uk'37 SST from the Iberian Margin $\left({ }^{\circ} \mathrm{C}\right.$; Martrat et al. (2007) tuned to the GLT_syn from Barker et al. 2011). Grey shaded areas are those regions of the core where no diatoms were preserved 
et al. 2008), but one which ultimately has wide ecological tolerances. Its dominance may be a result of a period of bottom water anoxia in Lake Van (as suggested by enhanced TOC values and laminated sediment in the intervals from which the samples were collected; Stockhecke et al. 2014a) leading to better diatom preservation. MIS7e is characterized by the brackish C. meneghiniana (Fig. 4), while samples from MIS5e are characterised by freshwater Stephanodiscus species and C. ocellata. Interestingly, the one sample from MIS7a (197.6 ka BP) has a floral assemblage very similar to the MIS5e assemblage, indicative of a freshwater, mesotrophic environment. From right to left therefore, DCA axis 1 captures snapshots of diatom assemblages in successively younger interglacials that suggest Lake Van may have become progressively deeper.

This inference is tentatively borne out by palaeoconductivity reconstructions. Palaeoconductivity for the one MIS11 sample was c. $37.8 \mathrm{mS} / \mathrm{cm}$, while MIS9 palaeoconductivity was on average very high (42.0 mS/cm) between 335.0-331.4 ka BP, likely because in the combined diatom training set used to model palaeoconductivity, $C$. choctawhatcheeana was common in shallow, chloride-dominated waters. Mean palaeoconductivity of Lake Van during MIS7e was $7.8 \mathrm{mS} / \mathrm{cm}$, while that during MIS5e was $1.3 \mathrm{mS} / \mathrm{cm}$. Current conductivity levels in the modern lake water $(20.2 \pm 4.6 \mathrm{mS} / \mathrm{cm})$ are therefore intermediate in value (Reimer et al. 2009).

The conversion of palaeoconductivities into palaeosalinities (PSs; see "Methods" section) results in $37-58 \mathrm{~g} / \mathrm{kg}$ for MIS11, 33-53 g/ $\mathrm{kg}$ for MIS9, $8.6 \pm 2.0 \mathrm{~g} / \mathrm{kg}$ for MIS7e, and $1.4 \pm 0.3 \mathrm{~g} / \mathrm{kg}$ for MIS5. Salinity ranges for MIS11 and MIS9 point to lower lake levels compared to the present lake level (see also Cukur et al. 2014b): -83 to $-155 \mathrm{~m}$ (MIS11) and -63 to $-141 \mathrm{~m}$ (MIS9). Palaeosalinity values for MIS7 and MIS5e differ significantly from each other and are lower than the modern salinity of about $23 \mathrm{~g} /$ $\mathrm{kg}$. These low PSs suggest higher lake levels with respect to the present situation. Tomonaga et al. (2017) inferred an open state of Lake Van during MIS7e and MIS5e based on the modelling of salinity of the pore waters. Our lake-level estimations based on the PSs indicate that this was indeed the case: both PSs lie below $13 \mathrm{~g} / \mathrm{kg}$ representing the salinity at which the lake would exceed the basin threshold located SW at approximately $1749 \mathrm{~m}$ a.s.l. (see the arrow indicating the past outflow of Lake Van in Fig. 1). The contour of the extension of Lake Van during MIS7e and MIS5e is plotted in Fig. 1. It is also worth noting that these Lake Van overflow stages (particularly during MIS5e) coincide with states of a connected Black and Mediterranean Sea (Badertscher et al. 2011). Given the very few samples analysed for MIS11 and MIS9, we only very tentatively suggest that lake levels were much lower compared to the present lake-level, inferred from palaeosalinities of $37-58 \mathrm{~g} / \mathrm{kg}$ (MIS11) and 33-53 g/kg (MIS9e).

The lake level differences between MIS7e and MIS5e may also reflect variability in the pollen record from Lake Van. Although the composition of the vegetation in the watershed during MIS7e was similar to that of MIS5e, total arboreal pollen was less than during MIS5e (Litt et al. 2014) perhaps indicative of the persistence of cooler winters (Roucoux et al. 2008) seen elsewhere in the eastern Mediterranean, e.g. Greece, where temperate forests also dominated MIS7e in contrast to deciduous broad-leaved forests during MIS5e (Roucoux et al. 2008). Further west, along the Iberian Margin, Uk'37-inferred sea-surface temperatures (SSTs) are consistently lower during MIS7e than MIS5e (Martrat et al. 2007). According to a hydroclimate reconstruction (see PC1 in Fig. 5) using a suite of proxy records sensitive to lake level fluctuations of Lake Van, and transient model simulations from an Earth System model LOVECLIM (Goosse et al. 2010), higher SSTs in the North Atlantic correspond to increased precipitation in the eastern Mediterranean (Stockhecke et al. 2016). Our results therefore support the correspondence of climate linkages between the North Atlantic and eastern Mediterranean.

\section{Conclusions}

Although previous Lake Van palaeolimnological investigations have found diatoms concentrated in Holocene sediments and absent in earlier deposits, this study identifies thin, isolated diatom sequences spanning no more than a few thousand years during earlier interglacial intervals. It is clear that each interglacial is characterised by different diatom assemblage, which appears to be related to prevailing climatic and hydrological conditions. Diatom assemblages in Lake Van during MIS7e were dominated by $C$. 
meneghiniana, which suggests that lake water levels were comparatively lower than MIS5e, resulting in higher palaeoconductivity (due to salt accumulation after an open stage) and possibly less stable bottom waters, which switched between anoxic and oxic states more frequently. During MIS5e, diatom assemblages were dominated by small-celled Stephanodiscus and Cyclotella species characteristic of fresh, relatively nutrient rich waters with increased stratification. This suggests that lake levels were high, that the lake was likely open, and that the bottom waters were, for fairly long periods of time, anoxic. Differences in palaeohydrology between MIS7e and MIS5e provide further evidence of close linkages between the North Atlantic and the Eastern Mediterranean during previous interglacials.

Acknowledgements We thank the PALEOVAN team for support during collection and sharing of data. The authors acknowledge funding of the PALEOVAN drilling campaign by the ICDP, the Deutsche Forschungsgemeinschaft (DFG), the Swiss National Science Foundation (SNF), and the Scientific and Technological Research Council of Turkey (Tübitak). This research was also supported by the funding from the EU Seventh Framework Programme for Research and Technological Development (Marie Curie International Outgoing Fellowship to YT, Contract PIOF-GA-2012-332404). Thanks go to A. Feray Meydan, Ismet Meydan, Sefer Örcen, and Mustafa Karabiyikoglu from the Yüzüncü Y1l Üniversitesi of Van, Turkey, for their cooperation.

Open Access This article is distributed under the terms of the Creative Commons Attribution 4.0 International License (http:// creativecommons.org/licenses/by/4.0/), which permits unrestricted use, distribution, and reproduction in any medium, provided you give appropriate credit to the original author(s) and the source, provide a link to the Creative Commons license, and indicate if changes were made.

\section{References}

Andersen K, Azuma N, Barnola J, Bigler M, Biscaye P, Caillon N, Chappellaz J, Clausen H, Dahl-Jensen D, Fischer H, Fluckiger J, Fritzsche D, Fujii Y, Goto-Azuma K, Gronvold K, Gundestrup N, Hansson M, Huber C, Hvidberg C, Johnsen S, Jonsell U, Jouzel J, Kipfstuhl S, Landais A, Leuenberger M, Lorrain R, Masson-Delmotte V, Miller H, Motoyama H, Narita H, Popp T, Rasmussen S, Raynaud D, Röthlisberger R, Ruth U, Samyn D, Schwander J, Shoji H, Siggard-Andersen M, Steffensen J, Stocker T, Sveinbjörnsdóttir A, Svensson A, Takata M, Tison J, Thorsteinsson T, Watanabe O, Wilhelms F, White J (2004) High-resolution record of Northern hemisphere climate extending into the last interglacial period. Nature 431:147-151
Anderson NJ (1994) Comparative planktonic diatom biomass responses to lake and catchment disturbance. J Plankton Res 16:133-150

Badaut D, Risacher F (1983) Authigenic smectite on diatom frustules in Bolivian saline lakes. Geochim Cosmochim Acta 47:363-375

Badertscher S, Fleitmann D, Cheng H, Edwards RL, Göktürk OM, Zumbühl A, Leuenberger M, Tüysüz O (2011) Pleistocene water intrusions from the Mediterranean and Caspian seas into the Black Sea. Nat Geosci 4(4):236-239

Barker PA (1990) Diatoms as paleolimnological indicators: a reconstruction of Late Quaternary environments in two East African salt lakes. Unpublished Ph.D. Thesis, University of Loughborough

Barker S, Knorr G, Edwards RL, Parrenin F, Putnam AE, Skinner LC, Wolff E, Ziegler M (2011) 800,000 years of abrupt climate variability. Science 334(6054):347-351

Bar-Matthews M, Ayalon A, Gilmour M, Matthews A, Hawkesworth CJ (2003) Sea-land oxygen isotopic relationships from planktonic foraminifera and speleothems in the Eastern Mediterranean region and their implication for paleorainfall during interglacial intervals. Geochim Cosmochim Acta 67(17):3181-3199

Battarbee RW, Kneen MJ (1982) The use of electronically counted microspheres in absolute diatom analysis. Limnol Oceanogr 27(1):184-188

Battarbee RW, Jones VJ, Flower RJ, Cameron NJ, Bennion H, Carvalho L, Juggins S (2001) Diatoms. Tracking environmental change using Lake sediments. Dev Paleoenviron Res 3:155-202

Battarbee RW, Mackay AW, Jewson D, Ryves DB, Sturm M (2005) Differential dissolution of Lake Baikal diatoms: correction factors and implications for palaeoclimatic reconstruction. Glob Planet Change 46:75-86

Birks HJB, Heiri O, Seppä H, Bjune AE (2010) Strengths and weaknesses of quantitative climate reconstructions based on late-quaternary biological proxies. Open Ecol J 3:68-110

Birks HJB, Felde VA, Bjune AE, Grytnes JA, Seppä H, Giesecke T (2016) Does pollen-assemblage richness reflect floristic richness? A review of recent developments and future challenges. Rev Palaeobot Palynol 228:1-25

Cheng H, Edwards RL, Broecker WS, Denton GH, Kong XG, Wang YJ, Zhang R, Wang XF (2009) Ice age terminations. Science 326(5950):248-252

Cruces F, Rivera P, Urrutia R (2010) Observations and comments on the diatom Stephanodiscus minutulus (Kützing) Cleve and Moeller (Bacillariopyceae) found for the first time in Chile from bottom sediments collected in Lake Laja. Gayana Botánica 67:12-18

Cukur D, Krastel S, Schmincke HU, Sumita M, Çağatay MN, Meydan AF, Damc1 E, Stockhecke M (2014a) Seismic stratigraphy of Lake Van, eastern Turkey. Quat Sci Rev 104:63-84

Cukur D, Krastel S, Schmincke HU, Sumita M, Tomonaga Y, Çağatay MN (2014b) Water level changes in Lake Van, Turkey, during the past ca. $600 \mathrm{ka}$ : climatic, volcanic and tectonic controls. J Paleolimnol 52(3):201-214

Cukur D, Krastel S, Çağatay MN, Damcı E, Meydan AF, Kim SP (2015) Evidence of extensive carbonate mounds and sublacustrine channels in shallow waters of Lake Van, 
eastern Turkey, based on high-resolution chirp subbottom profiler and multibeam echosounder data. Geo-Mar Lett 35(5):329-340

Degens ET, Kurtmann F (1978) The geology of Lake Van. MTA Press, Ankara, p 158

Degens ET, Wong HK, Kempe S, Kurtman F (1984) A geological study of Lake Van, Eastern Turkey. Geol Rundsch 73:701-734

Drysdale RN, Zanchetta G, Hellstrom JC, Fallick AE, Zhao J (2005) Stalagmite evidence for the onset of the last interglacial in southern Europe at $129 \pm 1 \mathrm{ka}$. Geophys Res Lett 32(24):L24708. doi:10.1029/2005GL024658

Farr TG, Rosen PA, Caro E, Crippen R, Duren R, Hensley S, Kobrick M, Paller M, Rodriguez E, Roth L, Seal D, Shaffer S, Shimada J, Umland J, Werner M, Oskin M, Burbank D, Alsdorf D (2007) The shuttle radar topography mission. Rev Geophys 45:Rg2004

Fritz SC, Cumming BF, Gasse F, Laird KR (2010) Diatoms as indicators of hydrologic and climatic change in saline Lakes. In: Smol JP, Stoermer EF (eds) The diatoms: applications for the environmental and earth sciences. Cambridge University Press, Cambridge, pp 186-208

Fritz SC, Baker PA, Tapia P, Spanbauer T, Westover K (2012) Evolution of the Lake Titicaca basin and its diatom flora over the last $\sim 370,000$ years. Palaeogeogr Palaeoclimatol Palaeoecol 317-318:93-103

Gasse F (1986) East African diatoms: Taxonomy, ecological distribution. Biblographie der Diatomologie., Band 11, J. Cramer, Stuttgart, p 201

Gasse F, Barker P, Johnson TC (2002) A 24,000 yr diatom record from the northern basin of Lake Malawi. In: Odada EO, Olago DO (eds) The East African great Lakes: limnology, paleolimnology and biodiversity. Kluwer Academic Publishers, Dordrecht, pp 393-414

Gasse F, Vidal L, Van Campo E, Demory F, Develle AL, Tachikawa K, Elias A, Bard E, Garcia M, Sonzogni C, Thouveny N (2015) Hydroclimatic changes in northern Levant over the past 400,000 years. Quat Sci Rev 111:1-8

Golobic S, Buch B (1978) Diatoms in sediment of Lake Van (Anatolia, Turkey). In: Degens ET, Kurtman F (eds) Geology of Lake Van. M.T.A. Press, Ankara, pp 111-126

Goosse H, Brovkin V, Fichefet T, Haarsma R, Huybrechts P, Jongma J, Mouchet A, Selten F, Barriat PY, Campin JM, Deleersnijder E (2010) Description of the earth system model of intermediate complexity LOVECLIM version 1.2. Geosci Model Dev 3:603-633

Guiry MD, Guiry GM (2014) AlgaeBase. World-wide electronic publication. National University of Ireland, Galway. http://www.algaebase.org

Hecky RE, Kilham P (1973) Diatoms in alkaline saline Lakes: ecology and geochemical implications. Limnol Oceanogr 18:53-71

Hecky RE, Bootsma HA, Mugidde RM, Bugenyi FWB (1996) Phosphorus pumps, nitrogen sinks, and silicon drains: plumbing nutrients in the African Great Lakes. In: Johnson TC, Odada EO (eds) The limnology, climatology, and paleoclimatology of the East African Lakes. Gordon and Breach Publishers, Amsterdam, pp 205-224

Hillebrand H, Dürselen CD, Kirschtel D, Pollingher U, Zohary T (1999) Biovolume calculations for pelagic and benthic microalgae. J Phycol 35:403-424
Houk V, Klee R, Tanaka H (2010) Atlas of freshwater centric diatoms with a brief key and descriptions. Part 3 . Stephanodiscaceae A. Cyclotella, Tertiarius. Discostella. Fottea 10 (Supplement):1-498

Interlandi SJ, Kilham SS (2001a) Limiting resources and the regulation of diversity in phytoplankton communities. Ecology 82(5):1270-1282

Interlandi SJ, Kilham SS (2001b) Limiting resources and the regulation of diversity in phytoplankton communities. Ecology 82:1270-1282

Jollifer IT (1986) Principal components analysis. Springer, New York

Jouzel J, Masson-Delmotte V, Cattani O, Dreyfus G, Falourd S, Hoffmann G, Minster B, Nouet J, Barnola JM, Chappellaz J, Fischer H, Gallet JC, Johnsen S, Leuenberger M, Loulergue L, Luethi D, Oerter H, Parrenin F, Raisbeck G, Raynaud D, Schilt A, Schwander J, Selmo E, Souchez R, Spahni R, Stauffer B, Steffensen JP, Stenni B, Stocker TF, Tison JL, Werner M, Wolff EW (2007) Orbital and millennial Antarctic climate variability over the past 800,000 years. Science 317:793-796

Juggins S (2001) The European diatom database. User Guide, Version 1, p. 72

Juggins S (2013) Quantitative reconstructions in palaeolimnolgy: new paradigm or sick science? Quat Sci Rev 64:20-32

Kaden H, Peeters F, Lorke A, Kipfer R, Tomonaga Y, Karabiyikoglu M (2010) Impact of Lake level change on deepwater renewal and oxic conditions in deep saline Lake Van, Turkey. Water Resour Res 46:7-70

Kelly MG, Bennion H, Cox EJ, Goldsmith B, Jamieson J, Juggins S, Mann DG, Telford RJ (2005) Common freshwater diatoms of Britain and Ireland: an interactive key. Environment Agency, Bristol

Khursevich GK, Karabanov EB, Prokopenko AA, Williams DF, Kuzmin MI, Fedenya SA, Gvozdkov AA (2000) Insolation regime in Siberia as a major factor controlling diatom production in Lake Baikal during the past 800,000 years. Quatern Int 80-81:47-58

Kilham P, Kilham SS, Hecky RE (1986) Hypothesized resource relationships among African planktinic diatoms. Limnol Oceanogr 31:1169-1181

Kiss KT, Klee R, Ector L, Ács É (2012) Centric diatoms of large rivers and tributaries in Hungary: morphology and biogeographic distribution. Acta Botanica Croatica 71:311-363

Krammer K, Lange-Bertalot H (1986) Bacillariophyceae: Naviculaceae. [Teil 1], 1-876. Stuttgart, Gustav Fischer. Süsswasserflora von Mitteleuropa. Bd. 2. Ettl H., Gerloff J., Heynig H., Mollenhauer D

Krammer K, Lange-Bertalot H (1988) Bacillariophyceae: Bacillariaceae, Epithemiaceae, Surirellaceae. [Teil 2], 1-596. Stuttgart, Gustav Fischer. Süsswasserflora von Mitteleuropa. Bd. 2. Ettl, H., Gerloff, J., Heynig, H., Mollenhauer, D

Krammer K, Lange-Bertalot H (1991a) Bacillariophyceae: Achnanthaceae, Kritische Ergänzungen zu Navicula (Lineolatae) und Gomphonema Gesamtliterarurverzeichnis. [Teil 4], 1-437. Stuttgart, Gustav Fischer. Süsswasserflora von Mitteleuropa. Bd. 2. Ettl, H., Gerloff, J., Heynig, H., Mollenhauer, D 
Krammer K, Lange-Bertalot H (1991b) Bacillariophyceae: Centrales, Fragilariaceae, Eunotiaceae. [Teil 3], 1-576. Stuttgart, Gustav Fischer. Süsswasserflora von Mitteleuropa. Bd. 2. Ettl, H., Gerloff, J., Heynig, H., Mollenhauer, D

Kukla GJ, Bender ML, de Beaulieu JL, Bond G, Broecker WS, Cleveringa P, Gavin JE, Herbert DH, Imbrie J, Jouzel J, Keigwin LD, Knudsen KL, McManus JF, Merkt J, Muhs DR, Muller H, Poore RZ, Porter SC, Seret G, Shackleton NJ, Turner C, Tzedakis PC, Winograd IJ (2002) Last interglacial climates. Quat Res 58:2-13

Kwiecien O, Stockhecke M, Pickarski N, Heumann G, Litt T, Sturm M, Anselmetti F, Kipfer R, Haug GH (2014) Dynamics of the last four glacial terminations recorded in Lake Van, Turkey. Quat Sci Rev 104:42-52

Lemcke G, Sturm M (1997) $\delta 180$ and trace element measurements as proxy for the reconstruction of climate changes at Lake Van (Turkey): preliminary results. In: Dalfes HN, Kukla G, Weiss H (eds) Third Millennium BC Climate Change and Old World Collapse. Springer, Berlin, pp 653-678 (2013)

Lepš J, Šmilauer P (2003) Multivariate analysis of ecological data using CANOCO. Cambridge University Press, Cambridge

Line JM, Birks HJB (1996) BSTICK Version 1.0. Unpublished computer program. Botanical Institute, University of Bergen, Bergen

Lisiecki LE, Raymo ME (2005) A pliocene-pleistocene stack of 57 globally distributed benthc $\delta^{18} \mathrm{O}$ records. Paleoceanography 20(1):PA1003

Litt T, Anselmetti FS, Baumgarten H, Beer J, Cagatay N, Cukur D, Damci E, Glombitza C, Haug G, Heumann G, Kallmeyer J, Kipfer R, Krastel S, Kwiecien O, Feray Meydan A, Ocen S, Pickarski N, Randlett ME, Schminke HU, Schubert CJ, Sturm M, Sumita M, Stochecke M, Tomonaga Y, Vigliotti L, Wonik T, Science Team PALEOVAN (2012) 500,000 years of environmental history in Eastern Anatolia: the PALEOVAN drilling project. Sci Drill 14:18-29

Litt T, Pickarski N, Heumann G, Stockhecke M, Tzedakis PC (2014) A 600,000 year long continental pollen record from Lake Van, eastern Anatolia (Turkey). Quat Sci Rev 104:30-41

Mackay AW (2007) The paleoclimatology of Lake Baikal: a diatom synthesis and prospectus. Earth Sci Rev 82:181-215

Mackay AW, Edlund MB, Khursevich G (2010) Diatoms in ancient Lakes. In: The diatoms: applications for the environmental and earth sciences, 2nd edn. pp. 209-228

Martrat B, Grimalt JO, Shackleton NJ, de Abreu L, Hutterlie MA, Stocker TF (2007) Four climate cycles of recurring deep and surface water destabilizations on the Iberian margin. Science 317:502-507

Milner AM, Müller UC, Roucoux KH, Collier RE, Pross J, Kalaitzidis S, Christanis K, Tzedakis PC (2013) Environmental variability during the last interglacial: a new highresolution pollen record from Tenaghi Philippon. Greece J Quat Sci 28(2):113-117

Mitrovic SM, Hitchcock JN, Davie AW, Ryan DA (2010) Growth responses of Cyclotella meneghiniana
(Bacillariophyceae) to various temperatures. J Plankton Res 32:1217-1221

Oliva MG, Lugo A, Alcocer J, Cantoral-Uriza EA (2008) Morphological study of Cyclotella choctawhatcheeana Prasad (Stephanodiscaceae) from a saline Mexican Lake. Saline Syst 4:17

Potapova M, Snoeijs P (1997) The natural life cycle in wild populations of Diatoma monoliformis (Bacillariophyceae) and its distribution in an aberrant environment. J Phycol 33:924-937

Prasad AKSK, Nienow JA (2006) The centric diatom genus Cyclotella (Stephanodiscaceae: bacillariaophyta) from Florida Bay, USA, with special reference to Cyclotella choctawhatcheeana and Cyclotella desikacharyi a new marine species related to the Cyclotella striata complex. Phycologia 45(2):127-140

Prasad AKSK, Nienow JA, Livingston RJ (1990) The genus Cyclotella (Bacillariophyta) in Choctawhatchee Bay, Florida, with special reference to $C$. striata and $C$. choctawhatcheeana sp. nov. Phycologia 29:418-436

Rasmussen SO, Andersen KK, Svensson AM, Steffensen JP, Vinther BM, Clausen HB, Siggaard-Andersen ML, Johnsen SJ, Larsen LB, Dahl-Jensen D, Bigler M, Röthlisberger R, Fischer H, Goto-Azuma K, Hansson ME, Ruth U (2006) A new Greenland ice core chronology for the last glacial termination. J Geophys Res 111(D6):D06102

Reimer A, Landmann G, Kempe S (2009) Lake Van, Eastern Anatolia, hydrochemistry and history. Aquat Geochem 15:195-222

Roucoux KH, Tzedakis PC, Frogley MR, Lawson IT, Preece RC (2008) Vegetation history of the marine isotope stage 7 interglacial complex at loannnina, NW Greece. Quat Sci Rev 27:1378-1395

Ryves DB, Jewson DH, Sturm M, Battarbee RW, Flower RJ, Mackay AW, Granin NG (2003) Quantitative and qualitative relationships between planktonic diatom communities and diatom assemblages in sedimenting material and surface sediments in Lake Baikal. Sib Limnol Oceanogr 48(4):1643-1661

Ryves DB, Battarbee RW, Juggins S, Fritz SC, Anderson NJ (2006) Physical and chemical predictors of diatom dissolution in freshwater and saline Lake sediments in North America and West Greenland. Limnol Oceanogr 51:1355-1368

Ryves DB, Battarbee RW, Fritz SC (2008) The dilemma of disappearing diatoms: incorporating diatom dissolution data into palaeoenvironmental modelling and reconstruction. Quat Sci Rev 28(1-2):1-17

Sayer CD (1997) The diatom ecology and palaeoecology of shallow Lakes subject to eutrophication: three examples from the English midlands. Ph.D. thesis, University of Loughborough

Schindler DW (2009) Lakes as sentinels and integrators for the effects of climate change on watersheds, airsheds, and landscapes. Limnol Oceanogr 54:2349-2358

Sengoer AMC, Goeruer N, Saroglu F (1986) Strike-slip faulting and related basin formation in zones of tectonic escape: Turkey as a case study. In: Biddle KT, Christie-Black N (eds) Strike-slip Faulting and basin formation. Soc Econ Paleont Min Spec Publ 37:227-264 
Shafik HM, Herodek S, Vörös L, Présing M, Kiss KT (1997) Growth of cyclotella meneghiniana Kütz. I. Effects of temperature, light and low rate of nutrient supply. Ann Limnol 33:139-147

Smol JP, Stoermer EF (2010) The diatoms: applications for the environmental and earth sciences. University Press, Cambridge

Stager JC, Cumming B, Meeker L (1997) A high-resolution 11,400-yr diatom record from Lake Victoria. East Africa. Quat Res 47(1):81-89

Stockhecke M, Anselmetti FS, Meydan AF, Odermatt D, Sturm M (2012) The annual particle cycle in Lake Van (Turkey). Palaeogeogr Palaeoclimatol Palaeoecol 333:148-159

Stockhecke M, Sturm M, Brunner I, Schmincke H-U, Sumita M, Kipfer R, Kwiecien O, Cukur D, Anselmetti FS (2014a) Sedimentary evolution and environmental history of Lake Van (Turkey) over the past 600,000 years. Sedimentology 61(6):1830-1861

Stockhecke M, Kwiecien O, Vigliotti L, Anselmetti FS, Beer J, Çağatay MN, Channell JET, Kipfer R, Lachner J, Litt T, Pickarski N, Sturm M (2014b) Chronostratigraphy of the 600,000 year old continental record of Lake Van (Turkey). Quat Sci Rev 104:8-17

Stockhecke M, Timmermann A, Kipfer R, Haug GH, Kwiecien O, Friedrich T, Menviel L, Litt T, Pickarski N, Anselmetti FS (2016) Millennial to orbital-scale variations of drought intensity in the Eastern Mediterranean. Quat Sci Rev 133:77-95

Stone JR, Westover KS, Cohen AS (2011) Late pleistocene paleohydrology and diatom paleoecology of the central basin of Lake Malawi, Africa. Palaeogeogr Palaeoclimatol Palaeoecol 303:51-70

Sundbäck K (1987) The epipsammic marine diatom Opephora olsenii Möller. Diatom Res 2:241-249

Svensson A, Andersen KK, Bigler M, Clausen HB, Dahl-Jensen D, Davies SM, Johnsen SJ, Muscheler R, Parrenin F, Rasmussen SO, Röthlisberger R, Seierstad I, Steffensen JP, Vinther BM (2008) A 60,000 year Greenland stratigraphic ice core chronology. Clim Past 4(1):47-57
Tomonaga Y, Brennwald MS, Kipfer R (2011) Spatial distribution and flux of terrigenic he dissolved in the sediment pore water of Lake Van (Turkey). Geochim Cosmochim Acta 75(10):2848-2864

Tomonaga Y, Blättler R, Brennwald MS, Kipfer R (2012) Interpreting noble-gas concentrations as proxies for salinity and temperature in the world's largest soda Lake (Lake Van, Turkey). J Asian Earth Sci 59:99-107

Tomonaga Y, Brennwald MS, Meydan AF, Kipfer R (2014) Noble gases in the sediments of Lake Van - solute transport and palaeoenvironmental reconstruction. Quat Sci Rev 104:117-126

Tomonaga Y, Brennwald MS, Livingstone DM, Kwiecien O, Randlett M-È, Stockhecke M, Unwin K, Anselmetti FS, Beer J, Haug GH, Schubert CJ, Sturm M, Kipfer R (2017) Porewater salinity reveals past Lake-level fluctuations in Lake Van, the Earth's largest soda Lake. Sci Rep 7(1):313

Turkish Office of Navigation, Hydrography and Oceanography. Bathymetry of Lake Van (Chart TR 9008) (1990)

Tzedakis PC, Hooghiemstra H, Pälike H (2006) The last 1.35 million years at Tenaghi Philippon: revised chronostratigraphy and long-term vegetation trends. Quat Sci Rev 25(23):3416-3430

Vigliotti L, Channell JET, Stockhecke M (2014) Paleomagnetism of Lake Van sediments: chronology and paleoenvironment since $350 \mathrm{ka}$. Quat Sci Rev 104:18-29

Wick L, Lemcke G, Sturm M (2003) Evidence of lateglacial and holocene climatic change and human impact in eastern Anatolia: high-resolution pollen, charcoal, isotopic and geochemical records from the laminated sediments of Lake Van. Turk. Holocene 13(5):665-675

Williams DF, Peck J, Karabanov EB, Prokopenko AA, Kravchinsky V, King J, Kuzmin MI (1997) Lake Baikal record of continental climate response to orbital insolation during the past 5 million years. Science 278(5340): 1114-1117

Winder M, Reuter JE, Schladow SG (2009) Lake warming favours small-sized planktonic diatom species. Proc R Soc B 279:427-435 